\title{
Considerations of the Physiological Variables That Determine the Blood Carboxyhemoglobin Concentration in Man *
}

\author{
R. F. Coburn, $\dagger$ R. E. Forster, and P. B. Kane \\ (From the Departments of Physiology, Graduate Division, and Medicine, School of Medicine, \\ University of Pennsylvania, Philadelphia, Pa.)
}

Numerous publications have considered the effects of inspiring high concentrations of $\mathrm{CO}$ on the venous blood carboxyhemoglobin concentration $[\mathrm{COHb}]$ in man (1-4). It appears, however, that no previous study has considered the physiological variables that determine $[\mathrm{COHb}]$ under conditions where inspired air $\mathrm{CO}$ concentrations are in the normal range. It has become apparent in recent years that $\mathrm{CO}$ is endogenously produced in normal man as a by-product of hemoglobin catabolism (and probably other hemoproteins as well) and therefore that the body $\mathrm{CO}$ stores are influenced by endogenous as well as exogenous $\mathrm{CO}(5,6)$. The development of a method of measuring the rate of endogenous $\mathrm{CO}$ production ( $\dot{V}_{\mathrm{CO}}$ ) in man (6) has made it possible to study the relationship of Vंco and other variables to $[\mathrm{COHb}]$. This is of particular interest since the latter has been used as an index of hemolysis (7). The Vंco has been shown to reflect quantitatively the rate of circulating erythrocyte hemoglobin destruction in normal subjects (8) and in patients with hemolytic anemia (9), and the accuracy of this index would depend on how closely [COHb] reflects Vco.

In this paper we have developed equations that appear to describe the major physiological variables that determine blood $[\mathrm{COHb}]$ under steady state and transient state conditions. We

* Submitted for publication May 10, 1965; accepted July $29,1965$.

Supported in part by a grant from the Life Insurance Medical Research Fund and by grant 3M01FR-40-05 from the Clinical Research Center, National Institutes of Health, Bethesda, Md.

† Address requests for reprints to Dr. Ronald F. Coburn, Dept. of Physiology, Graduate Division, University of Pennsylvania School of Medicine, Philadelphia, Pa.

Supported in part by the Pennsylvania Thoracic Society, 1963-1964. Recipient of a Career Development Award, no. 1-K3-HE-11,564-01, from the National Institutes of Health. have applied these equations to data obtained from $a$ ) normal subjects, $b$ ) male volunteers who breathed $100 \%$ oxygen for extended periods of time, and $c$ ) patients with elevated rates of endogenous $\mathrm{CO}$ production.

\section{Methods}

Air CO measurements. Samples of air taken from the "wards" of the Hospital of the University of Pennsylvania were analyzed for $\mathrm{CO}$ concentrations with an infrared $\mathrm{CO}$ meter. This instrument has an error (SD) of $\pm \mathbf{0 . 0 0 0 0 4 \%}$ $\mathrm{CO}$ and requires a $200-\mathrm{ml}$ sample. These samples were collected during the summer of 1964. Smoking is prohibited in the areas where these samples were collected. We also measured the $\mathrm{CO}$ concentrations in air samples taken from smoke-filled conference rooms, a small nonventilated room that we purposely filled with smoke by burning cigarettes, and a rural area well away from automobile combustion. Diurnal changes in blood [COHb] were measured in one subject and compared with the changes in percentage of $\mathrm{CO}$ in his environment. Blood [COHb] was determined by a method in which gas extracted from a $2-\mathrm{ml}$ blood sample is measured in the infrared $\mathrm{CO}$ meter. This method has an error (SD) of $\pm 0.03 \%[\mathrm{COHb}](10)$.

Washout experiments. Three normal young male subjects breathed $100 \%$ oxygen for 4 to 8 hours. The subjects were seated, wore a noseclip, and breathed the oxygen through a mouthpiece using an open circuit equipped with two one-way valves that directed the expired gas into a 100-L bag in a box, which was in turn connected to a Tissot spirometer. The inspired oxygen contained less than $0.00001 \% \mathrm{CO}$. At hourly intervals minute ventilation was measured, expired gas samples were collected and analyzed for $\mathrm{CO}$, and venous blood was drawn and analyzed for $[\mathrm{COHb}]$. The rate of $\mathrm{CO}$ excretion $\left(\dot{\mathrm{VE}}_{\mathrm{CO}}\right)$ was calculated from the minute ventilation and $\mathrm{CO}$ concentration of the expired air. Alveolar ventilation $\left(\dot{\mathrm{V}}_{\mathrm{A}}\right)$ was calculated from the minute ventilation and respiratory frequency, assuming an anatomical dead space of $150 \mathrm{ml}$. The diffusing capacity of the lung was measured (11) at a separate sitting.

Patients with increased rates of endogenous CO production. The rate of $\mathrm{CO}$ production was measured in 13 patients with hemolytic anemia, all of whom had elevated Vंco. Some of these patients are described in another publication (9). Vंco was determined by the rebreathing method (6), which has a SD of $\pm 0.08 \mathrm{ml}$ per hour. The study was 
performed with the patient supine and at rest in the late morning or early afternoon. The patients were nonsmokers or had not smoked for 2 days before the study. Venous blood $[\mathrm{COHb}]$ was determined with a specimen drawn just before the Vंco measurement. In three of these patients the pulmonary diffusing capacity was also measured. Alveolar ventilation was estimated as above from the minute ventilation measured at rest. Venous blood hemoglobin concentrations were determined as cyanmethemoglobin. Total body hemoglobin was measured with the method of Sjöstrand (12).

\section{Results}

Air CO concentrations. The $\mathrm{CO}$ concentrations in ward air varied, in 40 measurements, from 0.00004 to $0.00045 \%$, averaging 0.00022 $\mathrm{SD} \pm 0.000098 \%$. These results and the time of day that the samples were collected are shown in Figure 1. Air taken from smoke-

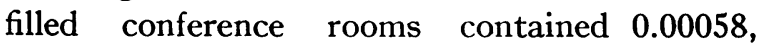
0.00043 , and $0.0009 \%$ CO. The concentration of $\mathrm{CO}$ in the air in the small room in which we burned 10 cigarettes was $0.002 \%$. The samples of rural air contained 0.00009 and $0.00004 \%$ CO. In the study in which the air $\mathrm{CO}$ per cent in a ventilated room and blood $[\mathrm{COHb}]$ in a normal subject isolated in the room were monitored for 48 hours, air $\mathrm{CO}$ per cent varied from 0.00007 to $0.0004 \%$, and [COHb] varied from $0.72 \%$ to $1.13 \%$. These data are graphed in Figure 2.

Washout experiments. The venous [COHb] and rate of excretion of $\mathrm{CO}$ during the oxygen breathing experiments are plotted in Figure 3. Both decreased during the first 3 to 4 hours and then remained fairly constant during the remainder of the experiments, and it appeared that the subjects had reached a new steady state.

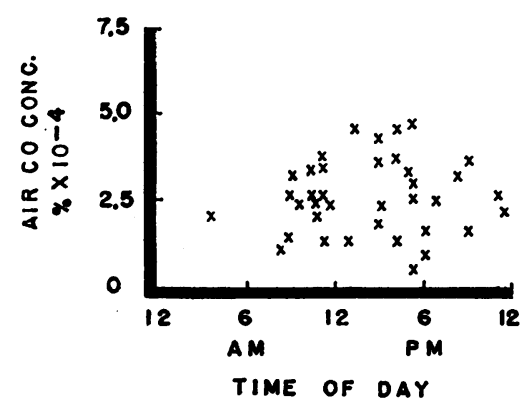

Fig. 1. CO concentrations in WARD aIR. This graph illustrates the extent of variation in air $\mathrm{CO}$ per cent that occurred over a period of several months. These measurements were made with an infrared $\mathrm{CO}$ meter.

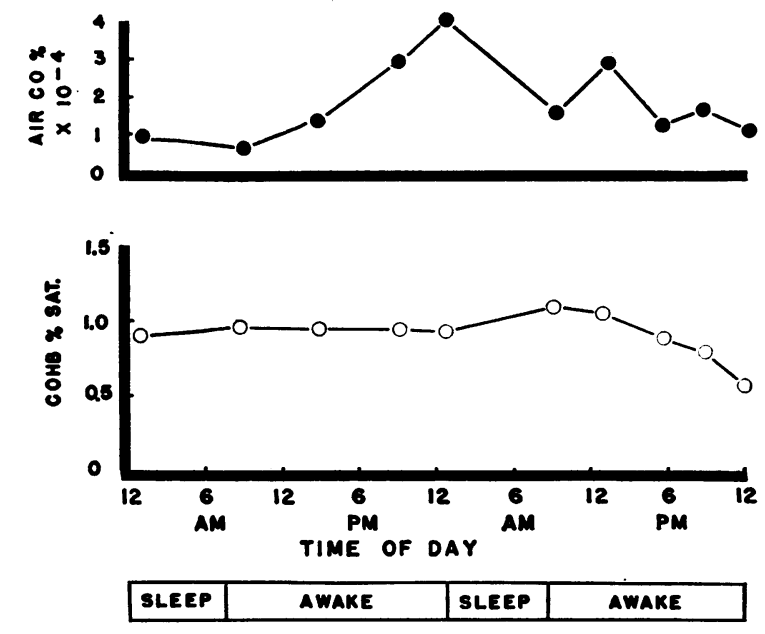

Fig. 2. Measured diurnal Changes in blood CarBOXYHEMOGLOBIN PER CENT SATURATION IN A NORMAL MALE SUBJECT. This study was performed in order to determine the degree of diurnal variation in blood carboxyhemoglobin concentration $[\mathrm{COHb}]$ that might occur in a normal subject. The subject was isolated in a ventilated room, and blood $[\mathrm{COHb}]$ and air $\mathrm{CO}$ concentrations were deternined every 4 to 6 hours for a total of 48 hours.

Steady state $[\mathrm{COHb}]$ averaged $0.12,0.12$, and $0.10 \%$ in the three experiments. Steady state $\dot{\mathrm{V}} \mathrm{E}_{\mathrm{CO}}$ was $0.48,1.50$, and $0.73 \mathrm{ml}$ per hour, respectively. The times during which $[\mathrm{COHb}]$ decreased to $50 \%$ of the total drop, or the time constants, were 60,61 , and 60 minutes. Average $\dot{V}_{A}$ in these experiments were 8.0,5.3, and $5.5 \mathrm{~L}$ per minute. The pulmonary diffusing capacities were $20.5,32$, and $30 \mathrm{ml}$ per minute per $\mathrm{mm} \mathrm{Hg}$. These data are also listed in Table I.

Data from the patients with increased rates of endogenous $C O$ production. These results are listed in Table II. Vंco varied from 0.70 to $3.44 \mathrm{ml}$ per hour. [COHb] ranged from 0.81 to $2.65 \%$. All of the patients studied were anemic with blood hemoglobin concentrations as low as $5.6 \mathrm{~g}$ per $100 \mathrm{ml}$. Resting $\dot{\mathrm{V}}_{\mathrm{A}}$ and lung diffusing capacity (DL) from three of these patients are also listed in Table II. The measured Vंco are plotted versus measured $[\mathrm{COHb}]$ in Figure 4.

\section{Discussion}

A) Development of theoretical equations. To determine the influence of the variables affecting blood $[\mathrm{COHb}]$ and the exchange of $\mathrm{CO}$ with the ambient, we have developed a relationship between blood [COHb], the rate of $\mathrm{CO}$ production, 


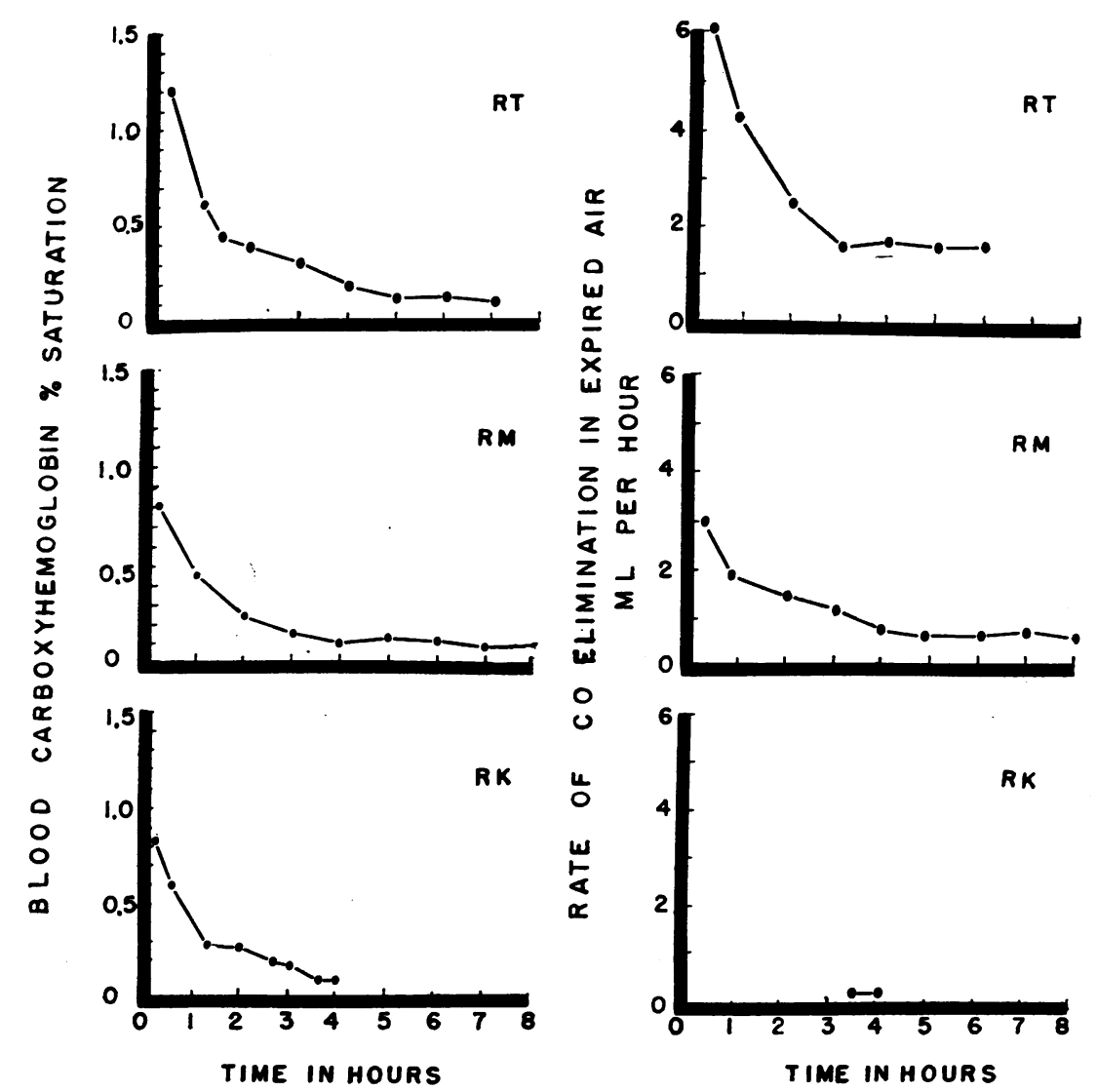

Fig. 3. OXYGen BREATHING EXPERIMENTs. Three normal volunteers (RT, RM, and RK) breathed $100 \%$ oxygen for 5 to 7 hours in order to "wash out" the body $\mathrm{CO}$ stores and achieve a new steady state at a lower blood [COHb], where the entire body $\mathrm{CO}$ stores were made up of endogenously produced $\mathrm{CO}$. The rate of $\mathrm{CO}$ excretion ( $\left.\dot{V}_{\mathrm{CO}}\right)$ and the blood $[\mathrm{COHb}]$ are plotted versus time. In the experiment on RK, VEco was determined only during the last hour.

and the rate of respiratory exchange. In these derivations we have made the following assumptions: 1 ) The entire body $\mathrm{CO}$ stores are always equilibrated with blood $[\mathrm{COHb}]$. 2) The partial pressure of $\mathrm{CO}$ is the same in all alveoli, and therefore the lung behaves as a single bag. 3) The lung washout time is not significant; therefore, we need not consider exchanges in $\mathrm{CO}$

TABLE I

Comparison of calculated with measured carboxyhemoglobin in washout experiments*

\begin{tabular}{|c|c|c|c|c|c|c|c|c|c|}
\hline \multirow[b]{2}{*}{ Subject } & \multirow[b]{2}{*}{ Age } & \multirow[b]{2}{*}{ Weight } & \multirow[b]{2}{*}{ Height } & \multirow[b]{2}{*}{$\dot{\mathbf{V}}_{\mathbf{A}}$} & \multirow[b]{2}{*}{ DL } & \multirow[b]{2}{*}{$\dot{\mathrm{V}} \mathrm{co}$} & \multirow[b]{2}{*}{$\overline{\mathrm{PCO}}_{2}$} & \multicolumn{2}{|c|}{$[\mathrm{COHb}]$} \\
\hline & & & & & & & & Measured & Calculated $\dagger$ \\
\hline & years & pounds & inches & $L /$ minute & $\begin{array}{c}m l / m i n u t e \\
\times m m B g\end{array}$ & $m l / m i n$ & $m m H g$ & $\begin{array}{c}\% \text { satur- } \\
\text { ation }\end{array}$ & $\begin{array}{c}\text { \% satur- } \\
\text { ation }\end{array}$ \\
\hline $\begin{array}{l}\text { RK } \\
\text { RT } \\
\text { RM }\end{array}$ & $\begin{array}{l}30 \\
23 \\
29\end{array}$ & $\begin{array}{l}128 \\
143 \\
188\end{array}$ & $\begin{array}{l}67 \\
69 \\
67\end{array}$ & $\begin{array}{l}8.0 \\
5.3 \\
5.5\end{array}$ & $\begin{array}{l}20.5 \\
32.0 \\
30.0\end{array}$ & $\begin{array}{l}0.48 \\
1.50 \\
0.73\end{array}$ & $\begin{array}{l}670 \\
670 \\
670\end{array}$ & $\begin{array}{l}0.12 \\
0.12 \\
0.10\end{array}$ & $\begin{array}{l}0.05 \\
0.16 \\
0.08\end{array}$ \\
\hline
\end{tabular}

* Abbreviations: $\dot{\mathrm{V}}_{\mathrm{A}}=$ alveolar ventilation; $\mathrm{DL}=$ pulmonary diffusing capacity; $\dot{\mathrm{V}} \mathrm{co}=$ rate of endogenous $\mathrm{CO}$ production; $\overline{\mathrm{Pco}_{2}}=$ mean pulmonary capillary $\mathrm{O}_{2}$ tension; and $[\mathrm{COHb}]=$ blood carboxyhemoglobin.

$\dagger$ Calculated from measured $\dot{V}$ co, DL, and $\dot{V}_{A}$. 
TABLE II

Principal parameters in subjects with elevated rates of $C O$ production

\begin{tabular}{|c|c|c|c|c|c|c|c|}
\hline \multirow[b]{2}{*}{ Patient } & \multirow{2}{*}{$\begin{array}{c}\text { Blood } \\
\text { hemoglobin }\end{array}$} & \multirow{2}{*}{$\begin{array}{c}\text { Total } \\
\text { hemoglobin }\end{array}$} & \multirow[b]{2}{*}{$\dot{\mathrm{V}}_{\mathbf{A}}$} & \multirow[b]{2}{*}{$D_{\mathbf{L}}$} & \multirow[b]{2}{*}[\mathrm{COHb}]{} & \multicolumn{2}{|c|}{$\dot{\text { V́co }}$} \\
\hline & & & & & & Measured & Theoretical* \\
\hline & $\mathrm{g} / 100 \mathrm{ml}$ & $g$ & $L /$ minute & $\begin{array}{l}m l / m i n \\
\times m m ~ \\
m g\end{array}$ & $\%$ saturation & ml/hour & $m l / h o u r$ \\
\hline HM & 11.0 & 518 & & & 2.40 & 2.60 & \\
\hline $\mathrm{GH}$ & 7.40 & 235 & & & 2.00 & 1.60 & \\
\hline $\mathrm{AU}$ & 10.2 & 380 & & & 2.74 & 2.08 & \\
\hline MC & 7.0 & 349 & & & 1.34 & 0.70 & \\
\hline $\mathrm{FS}_{1}$ & 9.1 & 467 & & & 0.81 & 0.76 & \\
\hline $\mathrm{FS}_{2}$ & 5.6 & 306 & 6.62 & 29 & 2.47 & 1.07 & 3.30 \\
\hline $\mathrm{CJ}$ & 11.0 & 621 & 7.50 & 26.2 & 1.65 & 1.50 & 1.90 \\
\hline IB & 7.8 & 430 & 5.35 & 18.4 & 2.11 & 3.44 & 2.54 \\
\hline GW & 8.1 & 506 & & & 2.12 & 3.42 & \\
\hline MV & 12.8 & 562 & & & 1.97 & 1.95 & \\
\hline LM & 9.8 & 368 & & & 1.04 & 1.03 & \\
\hline BS & 5.6 & 196 & & & 2.65 & 1.61 & \\
\hline $\mathrm{KA}$ & 10.2 & 400 & & & 1.58 & 1.07 & \\
\hline
\end{tabular}

* Calculated from measured $[\mathrm{COHb}], \dot{\mathrm{V}}_{\mathrm{A}}$, and DL.

stored in the lung gases. 4) Inspiratory and expiratory minute volume are equal. 5) $\mathrm{CO}$ exchange takes place only via the lungs.

The change in total body stores of $\mathrm{CO}$ with time can be described as follows:

$$
\frac{\mathrm{d} \mathrm{CO}}{\mathrm{dt}}=\dot{\mathrm{V}} \mathrm{CO}-\mathrm{DL}_{\mathrm{L}}\left(\overline{\mathrm{Pc}}_{\mathrm{CO}}-\mathrm{PA}_{\mathrm{CO}}\right) \text {. }
$$

$\mathrm{CO}$ is the amount of this gas in the body in milliliters standard temperature, pressure, dry (STPD).

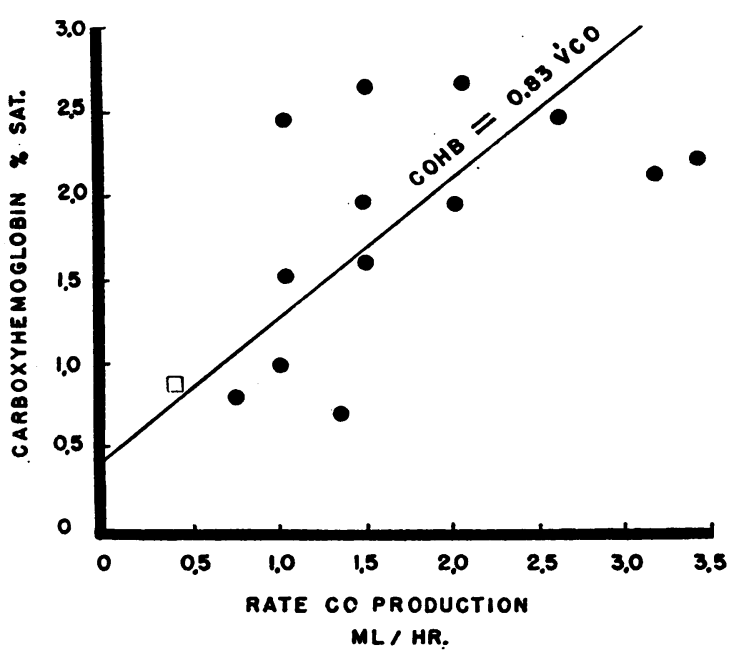

Fig. 4. Relationship of the Rate of CO PRODUCtion AND VENOUS BLOOD CARBOXYHEMOGLOBIN CONCENTRATION in PATIENTS With ElEVATED RATES OF CO PRODUCTION. Closed circles represent measurements from patients with elevated rates of $\mathrm{CO}$ production. $\square$ represents the average values in 10 normal patients breathing ward air. $\dot{\mathrm{V}} \mathrm{CO}=$ rate of endogenous $\mathrm{CO}$ production.
Vco is the rate of production of $\mathrm{CO}$ in the body in milliliters STPD per minute. $D_{L}$ is the pulmonary diffusing capacity in milliliters per minute per millimeter $\mathrm{Hg} . \quad \overline{\mathrm{Pc}}_{\mathrm{CO}}$ is the mean $\mathrm{CO}$ tension in equilibrium with the $[\mathrm{COHb}]$ in the pulmonary capillaries, and $\mathrm{PACO}_{\mathrm{CO}}$ is the alveolar $\mathrm{CO}$ tension, both in millimeters $\mathrm{Hg}$. The last term on the right is the loss of $\mathrm{CO}$ across the pulmonary membrane. The loss of $\mathrm{CO}$ via the lungs also equals the difference between the expired and inspired $\mathrm{CO}$.

$$
\frac{\mathrm{d} \mathrm{CO}}{\mathrm{dt}}=\dot{\mathrm{V}}_{\mathrm{CO}}-\frac{\dot{\mathrm{V}}_{\mathrm{A}}\left(\mathrm{PA}_{\mathrm{CO}}-\mathrm{PI}_{\mathrm{CO}}\right)}{\mathrm{P}_{\mathrm{B}}-\mathrm{PH}_{2} \mathrm{O}},
$$

where $\mathrm{V}_{\mathrm{A}}$ is the alveolar ventilation in milliliters STPD per minute; $\mathrm{PI}_{\mathrm{CO}}$ is the inspired $\mathrm{CO}$ tension in millimeters $\mathrm{Hg} ; \mathrm{PB}_{\mathrm{B}}$ is barometric pressure; and $\mathrm{PH}_{2} \mathrm{O}$ is the vapor pressure of water.

From Equations 1 and 2,

$$
\mathrm{PA}_{\mathrm{CO}}=\frac{\overline{\mathrm{P}}_{\mathrm{CO}}+\frac{\mathrm{P}_{\mathrm{ICO}_{\mathrm{C}}} \mathrm{V}_{\mathrm{A}}}{\mathrm{DL}_{\mathrm{L}}\left(\mathrm{PB}_{\mathrm{B}}-\mathrm{P}_{\mathrm{H}_{2} \mathrm{O}}\right)}}{\frac{\dot{\mathrm{V}}_{\mathrm{A}}}{\mathrm{DL}_{\mathrm{L}}\left(\mathrm{PB}_{\mathrm{B}}-\mathrm{PH}_{2} \mathrm{O}\right)}+1} .
$$

If chemical equilibrium is assumed to exist within the red cell, the Haldane relationship (13) can be used to calculate the equilibrated Pco in the pulmonary capillary blood.

$$
\overline{\mathrm{Pc}}_{\mathrm{CO}}=\frac{[\mathrm{COHb}] \overline{\mathrm{Pc}}_{\mathrm{O}_{2}}}{\left[\mathrm{O}_{2} \mathrm{Hb}\right] \mathrm{M}},
$$

$[\mathrm{COHb}]$ and $\left[\mathrm{O}_{2} \mathrm{Hb}\right]$ are in milliliters gas STPD per milliliter blood. This equation is not exact 
since the mean $\mathrm{O}_{2}$ tension $\left(\overline{\mathrm{Pc}}_{2}\right)$, and $\left[\mathrm{O}_{2} \mathrm{Hb}\right]$ vary along the capillary in a complicated fashion, but average values have been used here. It will also be assumed that $\left[\mathrm{O}_{2} \mathrm{Hb}\right]$ is constant. If we substitute in Equation 1,

$$
\begin{aligned}
& \frac{\mathrm{d} \mathrm{CO}}{\mathrm{dt}}=\dot{\mathrm{V}}_{\mathrm{CO}}-\frac{[\mathrm{COHb}] \overline{\mathrm{Pc}}_{2}}{\left[\mathrm{O}_{2} \mathrm{Hb}\right] \mathrm{M}} \\
& \times\left[\frac{1}{\frac{1}{\mathrm{DL}}+\frac{713}{\dot{\mathrm{V}}_{\mathrm{A}}}}\right]+\frac{\mathrm{PI}_{\mathrm{CO}}}{\frac{1}{\mathrm{DL}_{\mathrm{L}}}+\frac{713}{\dot{\mathrm{V}}_{\mathrm{A}}}}
\end{aligned}
$$

Total body $\mathrm{CO}$ stores are assumed to be proportional to blood $[\mathrm{COHb}]$ and equal to $[\mathrm{COHb}]$ $X$ effective blood volume in milliliters $(\mathrm{Vb})$. Substituting and integrating we obtain the general solution

$$
\begin{aligned}
& \frac{[\mathrm{COHb}] \overline{\mathrm{Pc}}_{\mathbf{2}}}{\left[\mathrm{O}_{2} \mathrm{Hb}\right] \mathrm{M}}-\dot{\mathrm{V}}_{\mathrm{CO}}\left[\frac{1}{\mathrm{DL}}+\frac{\mathrm{PB}-\mathrm{PH}_{2} \mathrm{O}}{\dot{\mathrm{V}}_{\mathrm{A}}}\right]-\mathrm{PI}_{\mathrm{CO}} \\
& \frac{[\mathrm{COHb}]_{0} \overline{\mathrm{Pc}}_{\mathrm{O}_{2}}}{\left[\mathrm{O}_{2} \mathrm{Hb}\right] \mathrm{M}}-\dot{\mathrm{V}} \mathrm{CO}\left[\frac{1}{\mathrm{DL}}+\frac{\mathrm{PB}_{\mathrm{B}}-\mathrm{PH}_{2} \mathrm{O}}{\dot{\mathrm{V}}_{\mathrm{A}}}\right]-\mathrm{PI}_{\mathrm{CO}} \\
& =e^{-\frac{\overline{\mathrm{PC}_{2} t}}{\mathrm{MVb}\left[\mathrm{O}_{2} \mathrm{Hb}\right]\left(\frac{1}{\overline{D L}}+\frac{713}{\dot{V}_{\mathrm{A}}}\right)} .}
\end{aligned}
$$

This equation describes the change in blood $[\mathrm{COHb}]$ with time from an original value, $[\mathrm{COHb}]_{0}$, when any of several parameters are suddenly altered to a new level and maintained there. A special case of interest is the steady state value reached after infinite time. Under these circumstances the right-hand terms become zero, and therefore the numerator on the left must also equal zero, and the steady state value of $[\mathrm{COHb}]$ is described by the relation,

$$
\begin{array}{r}
{[\mathrm{COHb}]=\frac{\mathrm{PICO}_{\mathrm{CO}}\left[\mathrm{O}_{2} \mathrm{Hb}\right]}{\overline{\mathrm{Pc}}_{\mathrm{O}_{2}}}+\frac{\dot{\mathrm{V}} \mathrm{CO} \mathrm{M}\left[\mathrm{O}_{2} \mathrm{Hb}\right]}{\overline{\mathrm{Pc}}_{\mathrm{O}_{2}}}} \\
\times\left[\frac{1}{\mathrm{DL}}+\frac{\mathrm{PB}_{\mathrm{P}}-\mathrm{PH}_{2} \mathrm{O}}{\dot{\mathrm{V}}_{\mathrm{A}}}\right] .
\end{array}
$$

It is important to note that $[\mathrm{COHb}]$ equals the sum of two terms, the first resulting from exogenous $\mathrm{CO}$ and equal to the $[\mathrm{COHb}]$ that would be in equilibrium with the inspired $\mathrm{PcO}$, the second resulting from the endogenous or produced $\mathrm{CO}$. The exogenous and endogenous $[\mathrm{COHb}]$ can be calculated independently and summated to get the total blood $[\mathrm{COHb}]$ :

$$
\begin{aligned}
{\left[\mathrm{COHb}_{\text {end }}\right]=\frac{\dot{\mathrm{V}} \mathrm{CO}\left[\mathrm{O}_{2} \mathrm{Hb}\right]}{\overline{\mathrm{Pc}}_{2}} } \\
\times\left[\frac{1}{\mathrm{DL}}+\frac{\mathrm{PB}-\mathrm{PH}_{2} \mathrm{O}}{\dot{\mathrm{V}}_{\mathrm{A}}}\right], \\
{\left[\mathrm{COHb}_{\text {ex }}\right]=\frac{\mathrm{PI}_{\mathrm{CO}} \mathrm{M}\left[\mathrm{O}_{2} \mathrm{Hb}\right]}{\overline{\mathrm{Pc}}_{\mathrm{O}_{2}}} . }
\end{aligned}
$$

B) Discussion of assumptions and theory. We have made a number of assumptions in the above derivations that require comment. The assumption that the $\mathrm{CO}$ stores in the blood are equilibrated with the "extravascular" CO stores is not rigorously correct under all conditions (i.e., transient states). The extravascular stores include $\mathrm{CO}$ bound to myoglobin and other compounds and make up a significant fraction (14) of the total body $\mathrm{CO}$. It has been shown in experiments where $\mathrm{CO}$ was added to the blood that it may take as long as 60 minutes for blood $\mathrm{CO}$ to equilibrate with extravascular $\mathrm{CO}$ (12). This time duration is, however, relatively short compared to that required to reach an equilibrium between the blood $\mathrm{CO}$ stores and ambient air, as will be shown later. Therefore, exchange between the blood and extravascular tissues should not be limiting, and error resulting from this exchange should not be significant.

In deriving the theoretical equations we assumed that the partial pressure of $\mathrm{CO}$ in alveolar air was dependent only on the rate of exchange across the alveolar membrane and alveolar ventilation. Mean alveolar $\mathrm{CO}$ tension, however, would also be influenced by the uniformity of DL to $\dot{V}_{A}$ throughout the lungs (15). Although this should not be a significant source of error in subjects with normal lungs, it is possible that considerable error might arise in applying these equations to patients with pulmonary disease.

It should be noted that DL is actually DL "out," from capillary blood to alveolar gas, rather than "in," from alveolar gas to capillary blood. Physical diffusion through the pulmonary membrane should be equal in both instances. Also, theoretically, there should be no difference between theta, the rate of gas uptake in blood in milliliters per minute for $1 \mathrm{~mm} \mathrm{Hg}$ of pressure gradient in $1 \mathrm{ml}$ blood versus the rate of escape 
of $\mathrm{CO}$ from red blood cells (16). There should be no error resulting from the use of DL "in" measurements in applying these equations.

We have assumed, in using the Haldane relationship in our equations, that chemical equilibration exists in the red blood cells in the pulmonary capillaries or that the mean capillary values of $\overline{\mathrm{Pc}}_{\mathrm{O}_{2}}, \overline{\mathrm{Pc}}_{\mathrm{CO}},[\mathrm{COHb}]$, and $\left[\mathrm{O}_{2} \mathrm{Hb}\right]$ approximate equilibrated values. Evidence is available that this assumption does not result in large errors. The equilibration constant, $\mathrm{M}$, determined in vivo with the subject rebreathing rapidly or holding his breath where the alveolar gas oxygen and $\mathrm{CO}$ tensions should approximate mean tensions in pulmonary capillary blood, has been found to be in the same range as that measured in tonometric studies (17). This indicates that the mean $\overline{\mathrm{Pc}}_{\mathrm{Co}}$ and $\overline{\mathrm{Pc}}_{\mathrm{O}_{2}}$ are close to the equilibrated values of these variables in normal man.

We have ignored the effects of $R Q$ and assumed that inspiratory and expiratory minute volume are equal. This assumption can cause an error of only $\pm 2 \%$. We have also assumed that mean capillary $\left[\mathrm{O}_{2} \mathrm{Hb}\right]$ is a constant with time; however, it must vary if $[\mathrm{COHb}]$ is changing when the blood is completely saturated. This assumption results in only a negligible error since $[\mathrm{COHb}]$ is so small under physiological conditions.

Evidence that $\mathrm{CO}$ exchange occurs only via the lung was obtained in experiments where we studied skin $\mathrm{CO}$ transport by placing patients up to their necks in bags containing high concentrations of $\mathrm{CO}$ (18). Skin CO exchange was less than $10 \mathrm{ml}$ per hour even with a $\mathrm{CO}$ gradient of over $700 \mathrm{~mm} \mathrm{Hg}$, and we reasoned that it could not be significant under normal conditions where the total gradient is probably less than $1 \mathrm{~mm} \mathrm{Hg}$. Error in our equations resulting from $\mathrm{CO}$ exchange with the environment via the skin is therefore considered to be insignificant.

In making calculations using the above equations we have assumed values for $\overline{\mathrm{Pc}}_{\mathrm{O}_{2}}$. In the instances where the patients breathed air we used $\overline{\mathrm{PC}}_{\mathrm{O}_{2}}$ as equal to $100 \mathrm{~mm} \mathrm{Hg}$; in the oxygen breathing studies we assumed $\overline{\mathrm{PC}}_{\mathrm{O}_{2}}$ to equal 670 $\mathrm{mm} \mathrm{Hg}$. The error introduced in breathing air for a variation in $\overline{\mathrm{Pc}}_{2}$ of $10 \mathrm{~mm} \mathrm{Hg}$ is less than $\pm 0.1 \%[\mathrm{COHb}]$; in oxygen breathing an uncertainty in $\overline{\mathrm{Pc}}_{\mathrm{O}_{2}}$ of $30 \mathrm{~mm} \mathrm{Hg}$ would result in an error of less than $0.02 \%$ [COHb]. The factor $\mathrm{M}$ is taken to be $250(13) . \quad\left[\mathrm{O}_{2} \mathrm{Hb}\right]$ is assumed to equal $100-[\mathrm{COHb}]$ per cent saturation or equivalent value in milliliters gas per milliliter blood. $\mathrm{Vb}$ is assumed to equal $5,000 \mathrm{ml}$.

Inspection of the derived equations reveals that there are two basic processes that determine the body $\mathrm{CO}$ stores and the blood [COHb], which we assume to be proportional to the total body stores. The first consists of production and excretion of endogenous $\mathrm{CO}$. $\mathrm{CO}$, which is apparently produced completely or mainly in the liver and spleen as a catabolic by-product of heme, diffuses into the blood and red blood cells, becomes bound to hemoglobin, and is diluted in the body $\mathrm{CO}$ stores. $\mathrm{CO}$ is apparently not metabolized in significant amounts by the body (19). It is excreted from the body via the lungs. In a steady state the rate of excretion is equal to the rate of production, and the body stores remain constant. Excretion of $\mathrm{CO}$ via the lungs is determined by the mean capillary-alveolar $\mathrm{CO}$ gradient and the diffusing capacity of the lungs. Mean $\overline{\mathrm{Pc}}_{\mathrm{CO}}$ depends on $\overline{\mathrm{Pc}}_{\mathrm{O}_{2}},\left[\mathrm{O}_{2} \mathrm{Hb}\right],[\mathrm{COHb}]$, and $\mathrm{M}$ as stated by the Haldane relationship. The average CO tension in the alveoli is assumed to be entirely dependent on the rate of removal of $\mathrm{CO}$ from the lung, the $\dot{\mathrm{V}}_{\mathrm{A}}$, and the rate of $\mathrm{CO}$ transport across the pulmonary membrane.

The second process is the uptake and excretion of exogenous $\mathrm{CO}$ via the lungs. This depends on the $\mathrm{CO}$ concentration in inspired air, DL, $\dot{\mathrm{V}}_{\mathrm{A}}$, and other variables in Equation 5. Since we have found air $\mathrm{CO}$ to be fairly constant in our wards (varies only $\pm 0.0001 \%$ ), we are concerned primarily with the "steady state" effects of exogenous CO. In this case, DL and $\dot{V}_{A}$ drop out of the equation, and $\left[\mathrm{COHb}_{\mathbf{e x}}\right]$ depends only on $\mathrm{PI}_{\mathrm{CO}}, \overline{\mathrm{Pc}}_{\mathrm{O}_{2}},\left[\mathrm{O}_{2} \mathrm{Hb}\right]$, and $\mathrm{M}$.

C) Theoretical effects of alveolar ventilation, diffusing capacity, oxygen tension, and inspired air $C O$ per cent. It is of theoretical and practical interest to determine how precisely the blood [COHb] reflects the $\dot{\mathrm{V}}_{\mathrm{CO}}$. If $\dot{\mathrm{V}}_{\mathrm{A}}, \mathrm{DL}_{\mathrm{L}}, \mathrm{P}_{\mathbf{C} \mathrm{Co}}$, and $\overline{\mathrm{PC}}_{\mathrm{O}_{2}}$ either are relatively invariant among individuals or have a relatively small influence on steady state $[\mathrm{COHb}]$, and if man is in approximately a steady state regarding his $\mathrm{CO}$ stores, then $[\mathrm{COHb}]$ would be an excellent index of 
Vco. We have calculated from Equations 8 and 9 the relative effects of changes in the determining parameters on $\left[\mathrm{COHb}_{\text {end }}\right]$ and $\left[\mathrm{COHb}_{e x}\right]$ and plotted the results in Figure 5. In each graph we have varied one parameter as indicated and kept the remaining ones constant. [COHb] is expressed in per cent saturation rather than in milliliters $\mathrm{CO}$ per milliliter blood as above. $\left[\mathrm{COHb}_{\text {end }}\right]$ is shown to be sensitive to changes in $\dot{\mathrm{V}}_{\mathrm{A}}, \mathrm{DL}$, and $\overline{\mathrm{P}}_{\mathrm{O}_{2}}$. For example, in a subject with a normal Vंco of $0.42 \mathrm{ml}$ per hour, an increase in $\dot{V}_{A}$ from 4 to $8 \mathrm{~L}$ per minute would result in a decrease in $\left[\mathrm{COHb}_{\text {end }}\right]$ from 0.37 to a new steady state value of $0.21 \%$. A change in DL from 30 to $15 \mathrm{ml}$ per minute per $\mathrm{mm} \mathrm{Hg}$, if $\dot{\mathrm{V}}_{\mathrm{co}}$ was $0.42 \mathrm{ml}$ per hour and other parameters were $\dot{\mathrm{V}}_{\mathrm{A}}=4 \mathrm{~L}$ per minute and $\overline{\mathrm{Pc}}_{\mathrm{O}_{2}}=100 \mathrm{~mm} \mathrm{Hg}$, would result in an increase of from 0.37 to $0.43 \%$. A change in $\overline{\mathrm{Pc}}_{\mathrm{O}_{2}}$ of $10 \mathrm{~mm} \mathrm{Hg}$ would result in a change in $\left[\mathrm{COHb}_{\text {end }}\right]$ of $0.05 \%$. It can be observed that the absolute effect of changes of the endogenous parameters $\dot{\mathrm{V}}_{\mathrm{A}}, \mathrm{DL}$, and $\overline{\mathrm{Pc}}_{\mathrm{O}_{2}}$ on $\left[\mathrm{COHb}_{\text {end }}\right]$ is considerably greater in patients with elevated $\dot{V}$ co. The influence of air $\mathrm{CO}$ per cent on $\left[\mathrm{COHb}_{\text {ex }}\right]$ is shown; the average $\left[\mathrm{COHb}_{\mathbf{e x}}\right]$ in patients in our ward, corresponding to an average air $\mathrm{CO}$ concentration of $0.00022 \%$, would be $0.39 \%$, as indicated in Figure 5 . The variation in $\left[\mathrm{COHb}_{e x}\right]$ that could occur as a result of the measured variation in $\mathrm{PI}_{\mathrm{CO}}$ is indicated by the interrupted lines and is equal to $\pm 0.17 \%$ SD.

D) Effects of diurnal changes and the time constants of $[\mathrm{COHb}]$ change. The above calculations were made assuming that a steady state existed. It is evident, however, that a steady state never actually exists in man, especially regarding ventilation, which varies with exercise throughout the day. There is evidence that $\dot{V}$ co is relatively constant throughout the day (9), but the possibility of a small diurnal change has not been excluded. The air concentration of $\mathrm{CO}$ has a diurnal variation depending on the extent of automobile and other combustion.

The effects on [COHb] of cyclic diurnal changes in the determining parameters depend
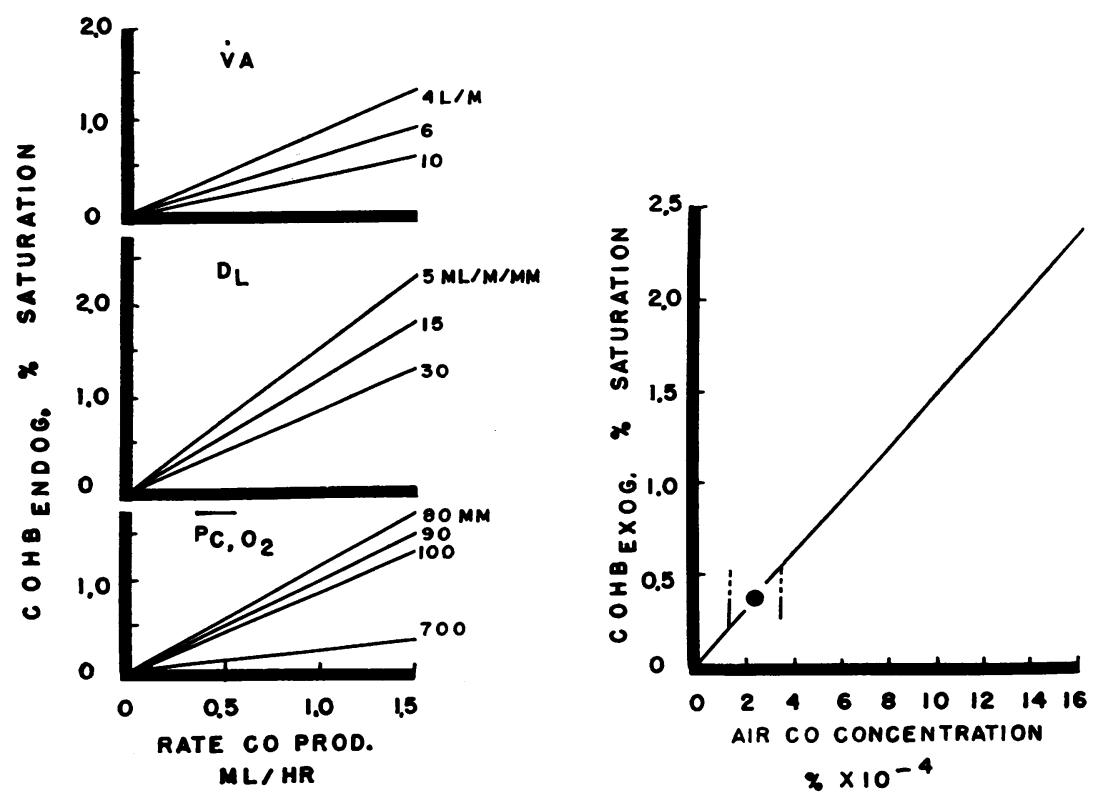

Fig. 5. THE EFFects OF ENDOGENOUS AND EXOGENOUS VARIABLES ON BLOOD CARBOXYHEMOGLOBIN PER CENT SATURATION. This figure demonstrates (left) the effect of changes of alveolar ventilation ( $\dot{V}_{A}$ ), diffusing capacity of the lung ( $D_{L}$ ), and mean capillary $\mathrm{O}_{2}$ tension $\left(\overline{\mathrm{Pc}}_{\mathrm{O}_{2}}\right)$ on endogenous blood carboxyhemoglobin concentration $\left[\mathrm{COHb}_{\text {endog }}\right]$, and (right) the effect of air $\mathrm{CO}$ concentration on exogenous blood carboxyhemoglobin concentration $\left[\mathrm{COHb}_{\text {exog }}\right]$. On the left, $\dot{\mathrm{V}}_{\mathrm{A}}$ is $4 \mathrm{~L}$ per minute, DL is $30 \mathrm{ml}$ per minute per $\mathrm{mm} \mathrm{Hg}$, and $\overline{\mathrm{Pc}}_{\mathrm{O}_{2}}$ is $100 \mathrm{~mm} \mathrm{Hg}$ unless otherwise noted. 
on the extent of "dampening" of the processes of $\mathrm{CO}$ exchange of body stores with inspired air in the lungs. If, for example, these processes are not highly damped, $[\mathrm{COHb}]$ would vary minute by minute with changes in $\dot{\mathrm{V}}_{\mathrm{A}}$, much like arterial carbon dioxide tension. If, however, they are highly damped, short duration cyclic variation would influence $[\mathrm{COHb}]$ minimally. Calculations using Equation 6 and solving for time demonstrate that the $[\mathrm{COHb}]$ changes very slowly after a change in a determining variable and that the system is, therefore, highly damped. The time constant (or half time) for a change of $\dot{V}_{A}$ from 8 to $4 \mathrm{~L}$ per minute, with DL equal to $30 \mathrm{ml}$ per minute per $\mathrm{mm} \mathrm{Hg}$ and $\overline{\mathrm{Pc}}_{\mathrm{O}_{2}}$ equal to $100 \mathrm{~mm} \mathrm{Hg}$, is calculated to be 418 minutes. Theoretical time constants for other values of $\dot{\mathrm{V}}_{\mathrm{A}}$ and $\overline{\mathrm{PC}}_{2}$ are shown in Figure 6. Half-time $\left(t_{\frac{1}{2}}\right)$ decreases when $\dot{\mathrm{V}}_{\mathrm{A}}$ or $\overline{\mathrm{Pc}}_{\mathrm{O}_{2}}$ increases. As in our other calculations, $\mathrm{Vb}$ is assumed to equal $5,000 \mathrm{ml}, \mathrm{M}$ to be equal to 250 , and $\left[\mathrm{O}_{2} \mathrm{Hb}\right]$ to be equal to $100-[\mathrm{COHb}]$. This effect of oxygen
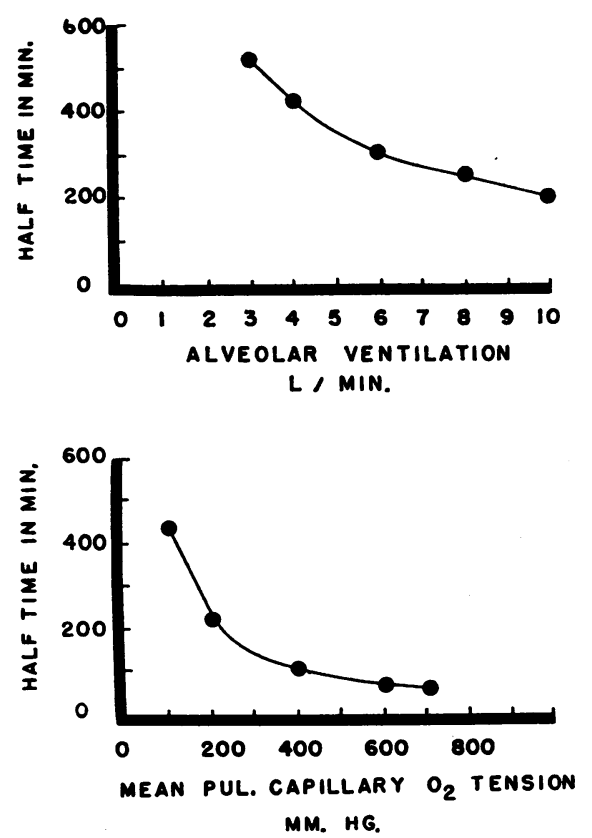

/ Fig. 6. EFFEct of ALveOlar ventilation AND MEAN PULMONARY CAPILLARY OXYGEN TENSION ON CALCULATED "TIME constants." Time constants are expressed in terms of half-times, or the time required to reach $50 \%$ of a new steady state after a change in a determining parameter. $\dot{\mathrm{V}}_{\mathrm{A}}$ is $4 \mathrm{~L}$ per minute, DL is $30 \mathrm{ml}$ per minute per $\mathrm{mm} \mathrm{Hg}$, $\overline{\mathrm{Pc}}_{\mathrm{O}_{2}}$ is $100 \mathrm{~mm} \mathrm{Hg}$, blood volume $(\mathrm{Vb})$ is $5,000 \mathrm{ml}$, and $\left[\mathrm{O}_{2} \mathrm{Hb}\right]-(100-\mathrm{COHb}$ per cent $)$, unless noted otherwise. is, of course, one of the reasons for the use of hyperbaric oxygen breathing in the treatment of $\mathrm{CO}$ poisoning. Half time with $\overline{\mathrm{Pc}}_{\mathrm{O}_{2}}$ of $700 \mathrm{~mm}$ $\mathrm{Hg}$ is 60 minutes, $t_{\frac{1}{2}}$ at 2 atmospheres oxygen is 40 minutes ( $\dot{V}_{A} 4 \mathrm{~L}$ per minute, DL $30 \mathrm{ml}$ per minute per $\mathrm{mm} \mathrm{Hg}$ ).

Short duration cyclic changes should not significantly influence $[\mathrm{COHb}]$ breathing air, but cyclic changes of longer duration might significantly alter $[\mathrm{COHb}]$. $\dot{\mathrm{V}}_{\mathbf{A}}$ varies diurnally, being lowest during sleep and varying while awake in a complex manner as a function of exercise and other variables. To estimate the changes in $\left[\mathrm{COHb}_{\text {end }}\right]$ that could occur as a result of diurnal variation in $\dot{V}_{A}$, we have calculated these changes for a theoretical case of a normal subject who had a $\dot{V}_{A}$ of $6 \mathrm{~L}$ per minute while awake and $4 \mathrm{~L}$ per minute while sleeping. Our calculations were made using an "awake" time duration of 16 hours, and 8 hours for the "asleep" period. $\dot{\mathrm{V}}$ co was assumed to be $\mathbf{0 . 4 2}$ $\mathrm{ml}$ per hour, DL and $\overline{\mathrm{Pc}}_{2}$ were kept constant at $30 \mathrm{ml}$ per minute per $\mathrm{mm} \mathrm{Hg}$ and $100 \mathrm{~mm} \mathrm{Hg}$. $\left[\mathrm{COHb}_{\text {ex }}\right]$ was assumed constant and equal to $0.39 \%$ for an air CO concentration of $0.00020 \%$. The results of these calculations are shown in Figure 7. $\left[\mathrm{COHb}_{e x}\right]$ is indicated by the stippled area of the diagram, and $\left[\mathrm{COHb}_{\text {end }}\right]$ is shown as the area above $\left[\mathrm{COHb}_{\text {ex }}\right]$ for two different values of $\dot{\mathrm{V}} \mathrm{CO}$. The calculated steady state $[\mathrm{COHb}]$ is indicated with interrupted lines and actual calculated $[\mathrm{COHb}]$ by the solid lines. $[\mathrm{COHb}]$ at the beginning of the awake period was $0.71 \%$ and dropped exponentially during this 16-hour period to a value of $0.67 \%$ at the beginning of the sleep period. The onset of a lower alveolar ventilation during sleep would result in an exponential rise to $0.71 \%$ at the beginning of the next cycle. We made identical calculations for a theoretical case where Vंco was $2.0 \mathrm{ml}$ per hour, and the total [COHb] varied from $1.68 \%$ at the beginning of the sleep period to $1.94 \%$ at the beginning of the awake period, again assuming all variables except $\dot{V}_{A}$ to be constant.

We measured the diurnal changes in [COHb] in a normal young male subject in order to compare "measured" with "theoretical" diurnal variation in $[\mathrm{COHb}]$. It is noted in Figure 2 where these data are plotted that $[\mathrm{COHb}]$ remained approximately constant during the first 


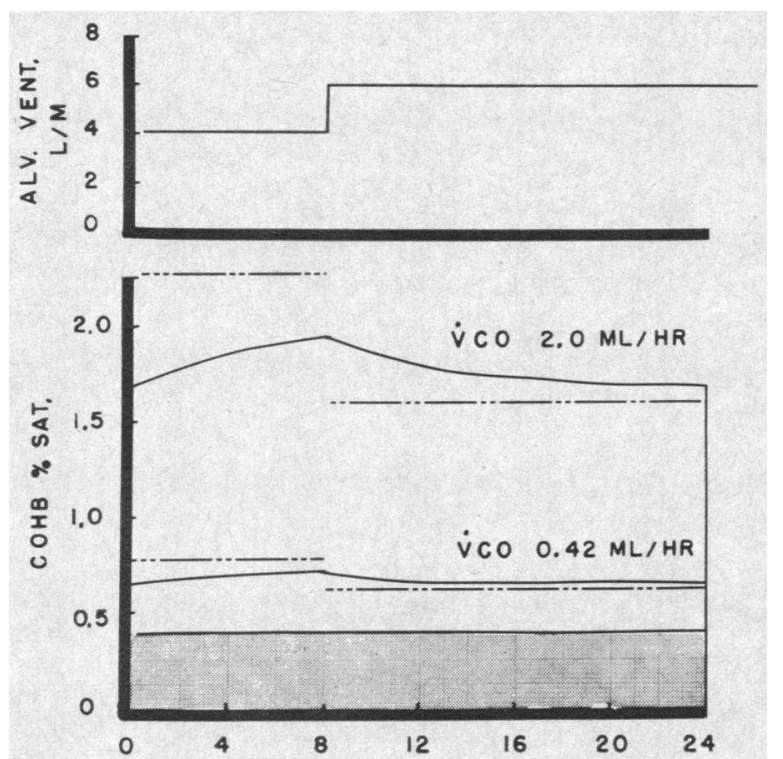

\begin{tabular}{|l|l} 
SLEEP & AWAKE \\
\hline
\end{tabular}

Fig. 7. TheORETICAL DIURNAL VARIATION IN BLOOD CARBOXYHEMOGLOBIN RESULTING FROM CHANGING ALVEOLAR VENTILATION. We calculated the diurnal variation in blood $[\mathrm{COHb}]$ that could occur as a result of changes in alveolar ventilation during sleep, as compared to the awake period. The other parameters were kept constant; DL was $30 \mathrm{ml}$ per minute per $\mathrm{mm} \mathrm{Hg}, \overline{\mathrm{Pc}}_{\mathrm{O}_{2}}$ was $100 \mathrm{~mm} \mathrm{Hg}$, $\mathrm{Vb}$ was $5,000 \mathrm{ml}$, and $\left[\mathrm{O}_{2} \mathrm{Hb}\right]-(100-\mathrm{COHb}$ per cent $)$. $\left[\mathrm{COHb}_{\text {ex }}\right]$ was constant at $0.40 \%$. Alveolar ventilation during the awake period was $6 \mathrm{~L}$ per minute and during the sleep period, $4 \mathrm{~L}$ per minute. We made these calculations for two different rates of $\mathrm{CO}$ production, $0.42 \mathrm{ml}$ per hour and $2.0 \mathrm{ml}$ per hour, as shown. Solid lines represent the $[\mathrm{COHb}]$ at any given time. The $[\mathrm{COHb}]$ is divided into $\left[\mathrm{COHb}_{\mathrm{ex}}\right]$, designated by the stippled area, and $\left[\mathrm{COH} \mathrm{b}_{\text {end }}\right]$. The interrupted lines illustrate the theoretical steady state $[\mathrm{COHb}]$ at any time.

awake period. Since the air $\mathrm{CO}$ per cent was increasing, it is suspected that $\left[\mathrm{COHb}_{\text {end }}\right]$ was decreasing, as would be expected with an increased awake $\dot{V}_{A}$. During the second awake period both air $\mathrm{CO}$ per cent and $[\mathrm{COHb}]$ decreased. Both $\left[\mathrm{COHb}_{\text {ex }}\right]$ and $\left[\mathrm{COHb}_{\text {end }}\right]$ probably decreased during this period. [COHb] increased during both asleep periods, as expected from the decreased $\dot{V}_{A}$ that presumably occurred with sleep.

Considerably greater diurnal variation in $[\mathrm{COHb}]$ was found in this subject compared to the theoretical case. In making the theoretical calculations only $\dot{V}_{A}$ was varied, and other endogenous variables and $\mathrm{PI}_{\mathrm{Co}}$ were assumed constant. The greater variation measured in our subject probably arose from changes in these variables. The measured decrease in air $\mathrm{CO}$ per cent on day 2 of the study could result in a maximal decrease in $[\mathrm{COHb}]$ of $0.5 \%$ and thereby completely explain the measured decrease in $[\mathrm{COHb}]$ during that day. It is possible that $\dot{V}_{A}$ varied more than $2 \mathrm{~L}$ per minute, the value assumed in our theoretical calculations, in our patient. The measured changes in $[\mathrm{COHb}]$ in our subject are consistent with our estimated diurnal variation in $\left[\mathrm{COHb}_{\text {ex }}\right]$ and $\left[\mathrm{COHb}_{\text {end }}\right]$. In patients with elevated $\dot{\mathrm{V}} \mathrm{CO}$, diurnal variation due to air $\mathrm{CO}$ changes should remain the same as with patients with normal $\dot{\mathrm{V}} \mathrm{Co}$, but variation due to endogenous variables would increase as shown in Figure 7.

E) Comparison of theoretical to measured carboxyhemoglobin per cent saturation. To determine the applicability of our theory to man we have compared measured $[\mathrm{COHb}]$ with that calculated from our equations, assuming a steady state for $a$ ) normal patients, $b$ ) subjects who breathed $100 \%$ oxygen for several hours and therefore should have had no exogenous $\mathrm{CO}$ in their body CO stores, and $c$ ) patients who had elevated Vंco. We also compared the measured rate of decrease of $[\mathrm{COHb}]$ in the oxygen breathing experiments with the calculated time constants for oxygen breathing.

As mentioned above, theoretical $\left[\mathrm{COHb}_{\text {ex }}\right]$ in patients breathing air on the wards should be approximately $0.39 \%$ as calculated from the measured air $\mathrm{CO}$ per cent with Equation 9. This value should be an estimate of the effect of exogenous $\mathrm{CO}$ on blood [COHb] in both normal patients and patients with elevated $\dot{V}$ co who were all housed in the areas where the air was sampled. Evidence that this figure is approximately correct was obtained from the plot of $\dot{V}_{\text {co }}$ and $[\mathrm{COHb}]$ in patients with elevated $\dot{\mathrm{V}} \mathrm{co}$ shown in Figure 4. The regression line drawn through these data intercepts the $\mathrm{Y}$ axis, where Vco is equal to zero, at $[\mathrm{COHb}]$ of $0.40 \%$. The calculated steady state $\left[\mathrm{COHb}_{\text {end }}\right]$ for normal subjects is $0.36 \%$ assuming a $\dot{V} \mathrm{CO}$ of 0.42 $\mathrm{ml}$ per hour, $\dot{V}_{A}$ equal to $4 \mathrm{~L}$ per minute, DL as $30 \mathrm{ml}$ per minute per $\mathrm{mm} \mathrm{Hg}$, and $\overline{\mathrm{Pc}}_{2}$ of 
$100 \mathrm{~mm} \mathrm{Hg}$. Total calculated $[\mathrm{COHb}]$ in normal man is then $0.39 \%$ plus $0.36 \%$ or $0.75 \%$. The average measured blood [COHb] in normal patients found on our wards is $0.88 \mathrm{SD} \pm 0.17 \%$ (10), comparing reasonably well with the theoretical $[\mathrm{COHb}]$.

The "washout" experiments were performed so that we could study patients in a steady state where all of the body CO originated from endogenous production. It is possible to reach a steady state after a relatively short period of oxygen breathing; the time constant is approximately 50 minutes, depending on $\mathrm{VA}_{\mathrm{A}}$ and $\mathrm{DL}$ as shown in Figure 6. CO is "washed out" of the body $\mathrm{CO}$ stores when $\overline{\mathrm{Pc}}_{2}$ is increased because $\overline{\mathrm{Pc}}_{\mathrm{Co}}$ also must increase as predicted by the Haldane equation, resulting in an increase in the rate of $\mathrm{CO}$ excretion. As [COHb] decreases, the $\overline{\mathrm{Pc}}_{\mathrm{CO}}$ correspondingly becomes smaller; therefore, the rate of $\mathrm{CO}$ washout falls until a new steady state is reached where $\dot{V} E_{C O}$ is equal to $\dot{V}$ co. A new steady state was reached in at least two of the experiments and probably in all three, as evidenced by the fact that $[\mathrm{COHb}]$ remained constant for 1 to 3 hours in the latter part of the experiments. We have calculated "theoretical" steady state $\left[\mathrm{COHb}_{\text {end }}\right]$ from Equation 7 with the measured values of $\mathrm{V}_{\mathrm{CO}}$ (assuming that it is equal to $\dot{V}_{\mathrm{CO}}$ ), $\dot{\mathrm{V}}_{\mathrm{A}}$, and $\mathrm{DL}_{\mathrm{L}}$, and assuming $\overline{\mathrm{Pc}}_{\mathrm{O}_{2}}$ to be $670 \mathrm{~mm} \mathrm{Hg}$. These values are listed in Table I adjacent to the measured steady state $[\mathrm{COHb}]$. It can be seen that they also compare closely, the average difference being only $0.06 \%$.

Steady state $\mathrm{VE}_{\mathrm{CO}}$ in these three experiments averaged $0.90 \mathrm{ml}$ per hour. As pointed out above, $\dot{\mathrm{V}} \mathrm{E}_{\mathrm{CO}}$ should equal $\dot{\mathrm{V}} \mathrm{co}$ in a steady state; however, this average value is considerably greater than the average $\dot{V}$ co found previously (6) in normal subjects as measured with the rebreathing method. This discrepancy can perhaps be explained by the recent finding of Helvey (20) and Mengel and Zirkle (21) that hyperoxia causes red blood cell damage and destruction. In our oxygen breathing experiments the elevated oxygen tension in arterial blood may have damaged red cells, resulting in an increased rate of red cell and hemoglobin catabolism and an increased Vंco.

We have also compared the measured time con- stants in the washout experiments with those calculated using Equation 6. The measured half time was, in each case, calculated to be about 60 minutes. The theoretical time constants were found to be 41,50 , and 48 minutes for Patients RT, RM, and RK, respectively. This discrepancy probably reflects lag in the washout of $\mathrm{CO}$ from extravascular stores, which in the case of oxygen breathing could be a limiting factor to $\mathrm{CO}$ excretion or an error due to other assumptions.

The relationship between measured [COHb] and $\dot{V}$ co in the patients with elevated $\dot{V}$ co was shown in Figure 4. The slope of this plot is 0.83 . As was mentioned above, the $\mathrm{Y}$ intercept of $[\mathrm{COHb}]$ is $0.40 \%$ and compares almost identically with calculated $\left[\mathrm{COHb}_{\text {ex }}\right]$. The slope of the regression line is equal to the average ratio of $\left[\mathrm{COHb}_{\text {ex }}\right] / \dot{\mathrm{V}} \mathrm{co}$. The theoretical ratio of $\left[\mathrm{COHb}_{\text {end }}\right] / \mathrm{V}_{\mathrm{CO}}$ as calculated from Equation 8 is equal to this experimentally determined value when DL is equal to $20 \mathrm{ml}$ per minute per $\mathrm{mm} \mathrm{Hg}$, $\dot{\mathrm{V}}_{\mathrm{A}}$ is equal to $5 \mathrm{~L}$ per minute, and $\overline{\mathrm{PC}}_{2}$ is equal to $100 \mathrm{~mm} \mathrm{Hg}$, which seem to be reasonable average values for these parameters in these patients, and therefore, the data obtained in these experiments also are consistent with those theoretically predicted with our equations.

The scatter found in Figure 4 cannot be explained on the basis of experimental error in the measurements of $\dot{\mathrm{V}} \mathrm{CO}$ and $[\mathrm{COHb}]$. Standard deviation in $\dot{V}$ co measurements is less than $\pm 0.1 \mathrm{ml}$ per hour and the standard deviation of $[\mathrm{COHb}]$ is $\pm 0.03 \%$. It can be shown that patient to patient variation of $\dot{\mathrm{V}}_{\mathrm{A}}, \mathrm{DL}, \overline{\mathrm{Pc}}_{\mathrm{O}_{2}}$, and $\mathrm{PI}_{\mathrm{CO}}$ can explain this scatter around the regression line. The effects of variation in the various parameters on $[\mathrm{COHb}]$, shown in Figure 5, can be expressed in terms of effects on the ratio of $\left[\mathrm{COHb}_{\text {end }}\right]$ and $\dot{\mathrm{V}}_{\mathrm{CO}}$. Variation of $\dot{\mathrm{V}}_{\mathrm{A}}$ from 5 to $10 \mathrm{~L}$ per minute will result in a variation in the ratio of from 0.83 to 0.4 , assuming $\mathrm{DL}$ and $\overline{\mathrm{Pc}}_{\mathrm{O}_{2}}$ equal to $30 \mathrm{ml}$ per minute per $\mathrm{mm} \mathrm{Hg}$ and 100 $\mathrm{mm} \mathrm{Hg}$, respectively. Variation of DL of from 20 to $5 \mathrm{ml}$ per minute per $\mathrm{mm} \mathrm{Hg}$ results in variation in $\left[\mathrm{COHb}_{\text {end }}\right] / \dot{\mathrm{V}}_{\mathrm{CO}}$ from 0.83 to 1.55 . Variation in $\mathrm{PI}_{\mathrm{CO}}$ can result in variation (standard deviation) of $\left[\mathrm{COHb}_{\mathrm{ex}}\right]$ of $\pm 0.17 \%$, as discussed above. 
In three patients, $\mathrm{CJ}, \mathrm{IB}$, and $\mathrm{FS}_{2}$, we measured $D_{L}$ and resting $\dot{V}_{A}$ and calculated a theoretical Vco from these values and the measured blood $[\mathrm{COHb}]$; the results of these calculations are listed in Table II. Here there is a discrepancy between calculated and measured $\dot{V}$ co. This may be explainable on the basis that we used resting $\dot{V}_{A}$ in our calculations and had no way of estimating the actual average or physiologically significant value. As we noted in the previous sections, [COHb] is sensitive to $\dot{\mathrm{V}}_{\mathrm{A}}$. It can be shown by Equation 8 that theoretical $\dot{V}_{C O}$ would equal measured $\dot{V}_{C O}$ if $\dot{V}_{A}$ in Patient IB were $10.8 \mathrm{~L}$ per minute, and in $\mathrm{CJ}, 4.0 \mathrm{~L}$ per minute. We could not explain the discrepancy between theoretical and measured $\dot{\mathrm{V}}_{\mathrm{CO}}$ on this basis with $\mathrm{FS}_{2}$. This patient was a smoker, and we suspected that he was exposed to high concentrations of exogenous $\mathrm{CO}$.

In the application of our theory to normal subjects, the volunteers who breathed oxygen, and the patients with elevated $\dot{\mathrm{V}} \mathrm{CO}$, the measured and theoretical data have correlated closely. We have concluded that even with the assumptions inherent in the derivations of the theory and the inaccuracies resulting from diurnal changes, the equations are applicable to man and are useful in explaining the processes that determine blood $[\mathrm{COHb}]$ levels.

$F)$ The usefulness of $[\mathrm{COHb}]$ measurements in the calculation of the rate of endogenous $\mathrm{CO}$ production. The theory developed in this paper and the measurements made on the patients with elevated $\dot{V}$ co have given us a basis for evaluating the blood $[\mathrm{COHb}]$ measurements as an index of $\dot{V}$ co. As mentioned above, the blood $[\mathrm{COHb}]$ has been used as an index of red blood cell destruction, particularly in Sweden. These workers, however, seem not to have considered that $[\mathrm{COHb}]$ might be influenced by variables other than $\dot{V}$ co. The theory developed in this paper demonstrates the influence of $\dot{\mathrm{V}}_{\mathrm{A}}, \mathrm{DL}, \overline{\mathrm{Pc}}_{\mathrm{O}_{2}}$, and $\mathrm{PI}_{\mathrm{CO}}$ on the total $[\mathrm{COHb}]$. From Figure 4 it is calculated that the average error in calculating $\dot{V}$ co from measured [COHb] in this group of patients with elevated $\dot{V}_{C O}$ is $\pm 0.80 \mathrm{ml}$ per hour SD.

Although $[\mathrm{COHb}]$ appears not to be a precise index of Vंco or of the rate of hemoglobin catabolism, it should be useful as a screening measure- ment. It is possible that $[\mathrm{COHb}]$ could be used to calculate $\dot{V}$ co with greater precision once the relationship of $[\mathrm{COHb}]$ and Vco was determined by measuring $\dot{V}_{\mathrm{CO}}$ in a given patient. This, of course, would depend on how constant average $\dot{\mathrm{V}}_{\mathrm{A}}, \mathrm{DL}_{\mathrm{L}}, \overline{\mathrm{Pc}}_{\mathrm{O}_{2}}$, and $\mathrm{PI}_{\mathrm{CO}}$ would remain over the period of time of the studies. It should be noted that it is imperative to determine the variability of exogenous $\mathrm{CO}$ exposure in evaluating blood $[\mathrm{COHb}]$ measurements. After exposure to high concentrations of $\mathrm{CO}$ in inspired air as occurs, for example, in a smoker, the blood [COHb] should not be measured until the patient has remained for at least 24 hours in an area where the air $\mathrm{CO}$ concentration is known.

G) The usefulness of $[\mathrm{COHb}]$ measurements in the calculation of exposure to exogenous $C O$. The equations presented in this paper can be used to estimate exposure to exogenous $\mathrm{CO}$ from measured values of $[\mathrm{COHb}]$. Previous studies (1-4) have been concerned with the relationships of exogenous $\mathrm{CO}$ and blood [COHb) but did not consider endogenous $\mathrm{CO}$ production and, therefore, these approaches have large errors when exposure to exogenous $\mathrm{CO}$ is relatively small. In the present study we have made measurements of the variation of exposure to exogenous $\mathrm{CO}$ in our hospital population and have used these data to estimate variation of $\left[\mathrm{COHb}_{\mathbf{e x}}\right]$ in this population; however, we have not made [COHb] measurements under conditions where the $\mathrm{CO}$ concentration in inspired air was very high nor have we attempted to estimate errors in our theory under these conditions. We have not extended our observations to studies of tobacco smokers although, of course, these patients have high $[\mathrm{COHb}](10)$ since tobacco smoke contains $\mathrm{CO}$. It should be possible to calculate the amount of tobacco smoke inhaled acutely or chronically from $[\mathrm{COHb}]$ measurements.

\section{Summary}

The relationships between the rate of endogenous $\mathrm{CO}$ production, blood carboxyhemoglobin per cent saturation and body $\mathrm{CO}$ stores, and $\mathrm{CO}$ exchange via the lungs have been analyzed. The body $\mathrm{CO}$ stores are influenced by two principal processes, the production and excretion of endogenous $\mathrm{CO}$, and the respiratory exchange of exogenous $\mathrm{CO}$. The principal physiological 
parameters are: 1) rate of $\mathrm{CO}$ production, 2) alveolar ventilation, 3) diffusing capacity of the lung, 4) mean oxygen tension in the pulmonary capillaries, and 5) concentration of $\mathrm{CO}$ in inspired air. Calculations are presented that demonstrate the relative influence of the determining parameters on the blood carboxyhemoglobin per cent saturation and body $\mathrm{CO}$ stores. The theoretical equations also demonstrate that the time constants of transient states are very long and that the blood carboxyhemoglobin is not markedly influenced by short duration cyclic variations of the determining variables. Measured values of blood carboxyhemoglobin compare closely with values calculated from our equations for normal patients and normal volunteers who breathed $100 \%$ oxygen for 5 to 7 hours and were probably in a steady state, evidence that the theory is applicable to man. It was shown that the blood carboxyhemoglobin measurement is not a precise index of $\dot{V}$ co since it is markedly influenced by other parameters. In a group of patients with hemolytic anemia the rate of $\mathrm{CO}$ production could be calculated from blood carboxyhemoglobin per cent saturation measurement with a precision of only $\pm 0.80 \mathrm{ml}$ per hour SD.

\section{Acknowledgments}

We gratefully acknowledge the expert technical assistance of Robert Ersek, Dolores Thyrum, Mary Friedman, Thomas R. Fisher, and Mary Kokosky, and the cooperation and help of Drs. William J. Williams and William S. Blakemore.

\section{References}

1. Forbes, W. H., F. Sargent, and F. J. W. Roughton. The rate of carbon monoxide uptake by normal men. Amer. J. Physiol. 1945, 143, 594.

2. Pace, N., W. V. Consolazio, W. A. White, Jr., and A. R. Behnke. Formulation of the principal factors affecting the rate of uptake of carbon monoxide by man. Amer. J. Physiol. 1946, 147, 352.

3. Allen, T. H., and R. W. Allard. Fundamental parameters influencing the accumulation and elimination of $\mathrm{CO}$ by adult human beings. U. S. Army Med. Res. Nutr. Lab., Astia Report 261, 1961.

4. Forster, R. E., W. S. Fowler, and D. V. Bates. Considerations on the uptake of carbon monoxide by the lungs. J. clin. Invest. 1954, 33, 1128.

5. Sjöstrand, T. Endogenous formation of carbon monoxide in man under normal and pathological conditions. Scand. J. clin. Lab. Invest. 1949, 1, 201.

6. Coburn, R. F., W. S. Blakemore, and R. E. Forster. Endogenous carbon monoxide production in man. J. clin. Invest. 1963, 42, 1172.

7. Engstedt, L. Endogenous formation of carbon monoxide in hemolytic disease. Acta med. scand. 1957, 159 (suppl. 332).

8. Coburn, R. F., W. J. Williams, and R. E. Forster. Effect of erythrocyte destruction on carbon monoxide production in man. J. clin. Invest. 1964, 43, 1098.

9. Coburn, R. F., W. J. Williams, S. B. Kahn, and R. E. Forster. Endogenous carbon monoxide production in patients with hemolytic anemia (abstract). J. clin. Invest. 1963, 42, 924.

10. Coburn, R. F., G. K. Danielson, W. S. Blakemore, and R. E. Forster, II. Carbon monoxide in blood: analytical method and sources of error. J. appl. Physiol. 1964, 19, 510.

11. Ogilvie, C. M., R. E. Forster, W. S. Blakemore, and J. W. Morton. A standardized breath holding technique for the clinical measurement of the diffusing capacity of the lung for carbon monoxide. J. clin. Invest. 1957, 36, 1.

12. Sjöstrand, T. A method of the determination of the total volume haemoglobin content of the body. Acta physiol. scand. 1949, 16, 211.

13. Haldane, J., and J. L. Smith. The absorption of oxygen by the lungs. J. Physiol. (Lond.) 1897, 22, 231.

14. Roughton, F. J. W., and W. S. Root. The fate of $\mathrm{CO}$ in the body during recovery from mild carbon monoxide poisoning in man. Amer. J. Physiol. 1946, 145, 239.

15. Forster, R. E. Exchange of gases between alveolar air and pulmonary capillary blood: pulmonary diffusing capacity. Physiol. Rev. 1957, 37, 391.

16. Forster, R. E. Diffusion of gases in Handbook of Physiology-Respiration I, Baltimore, Williams and Wilkins, 1964, p. 839.

17. Jones, R. H., M. F. Ellicott, J. B. Cadigan, and E. A. Gaensler. The relationship between alveolar and blood $\mathrm{CO}$ concentrations during breath holding. J. Lab. clin. Med. 1958, 51, 553.

18. Coburn, R. F., and R. E. Forster. Unpublished data.

19. Tobias, C. A., J. H. Lawrence, F. J. W. Roughton, W. S. Root, and M. I. Gregersen. The elimination of carbon monoxide from the human body with reference to the possible conversion of $\mathrm{CO}$ to $\mathrm{CO}_{2}$. Amer. J. Physiol. 1946, 145, 253.

20. Helvey, W. M. Effects of prolonged exposure to pure oxygen on human performance. Republic Aviation Corporation Report RAC 393-1 (ARD 806-701, NASA Nasr-92), 1962.

21. Mengel, C. E., and L. G. Zirkle. Mechanisms of RBC damage during in vivo hyperoxia. Clin. Res. 1965, $13,67$. 